Article

\title{
Degradation of Fucoxanthin to Elucidate the Relationship between the Fucoxanthin Molecular Structure and Its Antiproliferative Effect on Caco-2 Cells
}

\author{
Shiro Komba *, Eiichi Kotake-Nara and Wakako Tsuzuki \\ Food Component Analysis Unit, Food Research Institute, National Agriculture and Food Research Organization, \\ 2-1-12, Kannondai, Tsukuba, Ibaraki 305-8642, Japan; ekotake@affrc.go.jp (E.K.-N.); wakako@affrc.go.jp (W.T.) \\ * Correspondence: skomba@affrc.go.jp; Tel.: +81-29-838-7298
}

Received: 18 July 2018; Accepted: 2 August 2018; Published: 6 August 2018

\begin{abstract}
Fucoxanthin has an antiproliferative effect on cancer cells, but its detailed structure-activity correlation has not yet been elucidated. To elucidate this correlation, fucoxanthin was degraded by ozonolysis. The degraded compounds of fucoxanthin obtained by ozonolysis were purified by HPLC and analyzed by NMR. The polyene chain of fucoxanthin was cleaved by ozonolysis, and the fucoxanthin was divided into two types of cyclohexyl derivatives, one with a $\beta, \gamma$-epoxy ketone group and the other with an allenic bond. In order to elucidate the structure-activity correlation, Caco-2 cells (human colorectal carcinoma) were treated with fucoxanthin degradation compounds. It was found that the entire structure of fucoxanthin is not essential for its antiproliferative effect and that even a partial structure exerts this effect.
\end{abstract}

Keywords: fucoxanthin; ozonolysis; apo-fucoxanthinone; Caco-2; antiproliferative effect

\section{Introduction}

Fucoxanthin (1) is a xanthophyll-type carotenoid which is mainly distributed in brown algae [1-10]. It has been reported that it has anticarcinogenic [11-22], anti-obesity [23-25], anti-inflammatory [26], anti-angiogenic [27], and antioxidative [28] effects. We focused on the anticarcinogenic activity of fucoxanthin.

It is well known that fucoxanthin and its metabolite, fucoxanthinol, induce $\mathrm{G}_{1}$ cell-cycle arrest and apoptosis in various cell lines and can inhibit cancer development in animal models [22]. However, its detailed structure-activity correlation has not been elucidated, particularly regarding what kind of molecular structure of fucoxanthin is responsible for this activity. Therefore, we decided to decompose a fucoxanthin molecule in order to elucidate the detailed structure-activity relationship and elucidate the mechanisms involved in its antiproliferative effect. By investigating the antiproliferative effect using each part of the degraded fucoxanthin, the structure contributing to the activity was able to be elucidated.

Fucoxanthin has a very complicated structure, with an allenic bond, a polyene chain, an acetyl, and a $\beta, \gamma$-epoxy ketone group. In addition, the two six-membered ring derivatives bound by the polyene chain are not symmetrical, with one having an allenic bond and the other having a $\beta, \gamma$-epoxy ketone group. In particular, we focused on the two six-membered ring derivatives that are connected by a polyene chain. We anticipated that one of the two might contribute to this activity and separated them by cutting the polyene chain. In regard to its anti-obesity activity, the allenic bond on fucoxanthin may be a key structure, according to Miyashita et al. [25]. Using these two six-membered ring derivatives, the antiproliferative effect on Caco-2 cells was examined. Although Caco-2 cells have been widely 
used as a model of intestinal absorption, we used them here as colon cancer cells, as we did in our previous study [29].

In order to chemically decompose fucoxanthin, which is sensitive to light, acid, and basic conditions, it was necessary to perform the reaction under mild, neutral conditions. Therefore, ozone oxidation was chosen, in which the reaction proceeds in a neutral condition at a relatively low temperature, and only gas is used as a reagent. Ozone oxidation is a reaction involving the oxidization of a double bond to decompose it into two aldehydes. It was predicted that fucoxanthin has a polyene chain, and that ozone easily oxidizes the double bond and decomposes it into two six-membered ring derivatives.

\section{Results and Discussion}

\subsection{Chemistry}

Fucoxanthin was purified from wakame (Undaria pinnatifida) (1.09 $\mathrm{mg}$ fucoxanthin/g dry wakame), as referenced in previous experiments [30]. The ${ }^{1} \mathrm{H}-\mathrm{NMR}$ and ${ }^{13} \mathrm{C}-\mathrm{NMR}$ spectra were identical to those previously reported. Purified fucoxanthin was dissolved in dichloromethane/methanol, and ozone gas was bubbled through the stirred mixture at $0{ }^{\circ} \mathrm{C}$ for $2 \mathrm{~h}$ (Figure 1). We then replaced ozone gas with nitrogen gas, and dimethyl sulfide was added as a reducing agent. Silica gel was added to the reaction mixture to separate the polar substances. The degradation products of fucoxanthin were purified by reverse phase HPLC by detecting the absorbance at both $215 \mathrm{~nm}$ and $280 \mathrm{~nm}$ (Figure 2). Though many peaks appeared on the HPLC chart, the main peaks were collected and analyzed by NMR. Peak A in Figure 2, which has a strong absorbance at $280 \mathrm{~nm}$, was obtained at $1.87 \mathrm{mg}$ (6.9\% yield). On the other hand, peak B in Figure 2, which has a strong absorbance at $215 \mathrm{~nm}$, was obtained at $7.85 \mathrm{mg}$ (33\% yield). From the ESI-Orbitrap-MS analysis and ${ }^{1} \mathrm{H}-\mathrm{NMR}, \mathrm{COSY}-\mathrm{NMR},{ }^{13} \mathrm{C}-\mathrm{NMR}, \mathrm{HSQC}-\mathrm{NMR}$, and HMBC-NMR analyses, peak A in Figure 2 was identified as apo-13-fucoxanthinone (2) [4] (Table 1) and peak B in Figure 2 was identified as apo-9'-fucoxanthinone (3) [4] (Table 2). The NMR spectrum of apo-13-fucoxanthinone (2) (Figure S1), which has five methyl groups $\{\delta=0.94(\mathrm{~s}, 3 \mathrm{H}, \mathrm{Me}-15), 1.03(\mathrm{~s}, 3 \mathrm{H}, \mathrm{Me}-14), 1.21(\mathrm{~s}, 3 \mathrm{H}, \mathrm{Me}-16), 2.03(\mathrm{~s}, 3 \mathrm{H}$, Me-17), 2.35 (s, 3H, Me-18) ppm $\}$, three methylene groups $\{\delta=1.34$ and 1.50 (each $\mathrm{m}, 2 \mathrm{H}, \mathrm{H}-2 \mathrm{a}$ and $\mathrm{H}-2 \mathrm{~b}), 1.79$ and 2.31 (each m, 2H, H-4a and H-4b), 2.61 (d, 1H, Jgem $18.6 \mathrm{~Hz}, \mathrm{H}-7 \mathrm{a}), 3.63(\mathrm{~d}, 1 \mathrm{H}$, $\left.\left.J_{\text {gem }} 19.0 \mathrm{~Hz}, \mathrm{H}-7 \mathrm{~b}\right) \mathrm{ppm}\right\}$, three methine groups $\left\{\delta=6.46\left(\mathrm{~d}, 1 \mathrm{H}, J_{11,12} 15.4 \mathrm{~Hz}, \mathrm{H}-12\right), 7.05(\mathrm{~d}, 1 \mathrm{H}\right.$, $\left.\left.J_{10,11} 11.2 \mathrm{~Hz}, \mathrm{H}-10\right), 7.47\left(\mathrm{dd}, 1 \mathrm{H}, J_{10,11} 11.3 \mathrm{~Hz}, J_{11,12} 15.4 \mathrm{~Hz}, \mathrm{H}-11\right) \mathrm{ppm}\right\}$ and one oxymethine group $\{\delta=3.81(\mathrm{~m}, 1 \mathrm{H}, \mathrm{H}-3) \mathrm{ppm}\}$, agreed well with the NMR data of the compound reported by Mori et al. [4]. In addition, the NMR spectrum of apo-9'-fucoxanthinone (3) (Figure S2), which has four methyl groups $\left\{\delta=1.16\left(\mathrm{~s}, 3 \mathrm{H}, \mathrm{Me}-10^{\prime}\right), 1.43\left(\mathrm{~s}, 6 \mathrm{H}, \mathrm{Me}-11^{\prime}\right.\right.$ and $\left.\left.\mathrm{Me}-12^{\prime}\right), 2.19\left(\mathrm{~s}, 3 \mathrm{H}, \mathrm{Me}-13^{\prime}\right) \mathrm{ppm}\right\}$, one acetyl group $\{\delta=2.05(\mathrm{~s}, 3 \mathrm{H}, \mathrm{Ac}) \mathrm{ppm}\}$, two methylene groups $\left\{\delta=1.44\left(1 \mathrm{H}, \mathrm{H}-2^{\prime} \mathrm{a}\right), 1.53(\mathrm{dd}, 1 \mathrm{H}, J 11.4 \mathrm{~Hz}, J 12.9 \mathrm{~Hz}\right.$, H-4'a), 2.02 (dd, 1H, J $2.2 \mathrm{~Hz}, J 4.3 \mathrm{~Hz}, \mathrm{H}-2^{\prime} \mathrm{b}$ ), 2.33 (ddd, 1H, J $2.2 \mathrm{~Hz}, J 4.3 \mathrm{~Hz}, J 12.9 \mathrm{~Hz}, \mathrm{H}-4^{\prime}$ b) ppm $\}$, one methine group $\{\delta=5.87(\mathrm{~s}, 1 \mathrm{H}, \mathrm{H}-8) \mathrm{ppm}\}$, and one oxymethine group $\{\delta=5.39(\mathrm{tt}, 1 \mathrm{H}$, $\left.\left.J 4.2 \mathrm{~Hz}, J 11.5 \mathrm{~Hz}, \mathrm{H}-3^{\prime}\right) \mathrm{ppm}\right\}$ also agreed well with the NMR data of the compound reported by Mori et al. [4]. Since these two types of degradation product have already been found in edible brown algae cultivated in deep seawater by Mori et al. [4], there is a possibility that this experiment artificially reproduced the decomposition of fucoxanthin which occurs in nature. Furthermore, based on the discovery made by Mori et al. and the results from this experiment, positions 13 and $9^{\prime}$ of fucoxanthin are easily oxidatively cleavable sites in the polyene chain of fucoxanthin. As a result, we succeeded in separating the two six-membered rings.

\subsection{Biology}

These obtained compounds were evaluated for their antiproliferative activity using Caco- 2 cells. After $72 \mathrm{~h}$ of cultivation, cell viability was evaluated by 3-(4,5-dimethylthiazol-2-yl)-2,5-diphenyl tetrazolium bromide (MTT) assay [31] (Figure 3). As a result, it was found that each of the 
degraded compounds inhibited the proliferation of Caco-2 cells in a concentration-dependent manner. In addition, apo-9'-fucoxanthinone (3) was found to inhibit proliferation more strongly than apo-13-fucoxanthinone (2). However, its activity was weaker than that of the original fucoxanthin (1). Both structures may be necessary to exert a powerful effect like that of fucoxanthin. The synergistic effect of these two degraded compounds will be discussed in the future. Although the activity of apo-13-fucoxanthinone (2) has not been studied extensively, the activity of apo-9'-fucoxanthinone (3) has recently drawn attention. For example, anti-inflammatory effects [32-34] and hair growth effects [35] have been reported. Detailed examination of the fucoxanthin when decomposed will lead to the discovery of new activity of the degradation products. Furthermore, this study suggests that not only fucoxanthin itself, but also the degradation products, may exert effects as a mechanism of fucoxanthin's activity in humans.

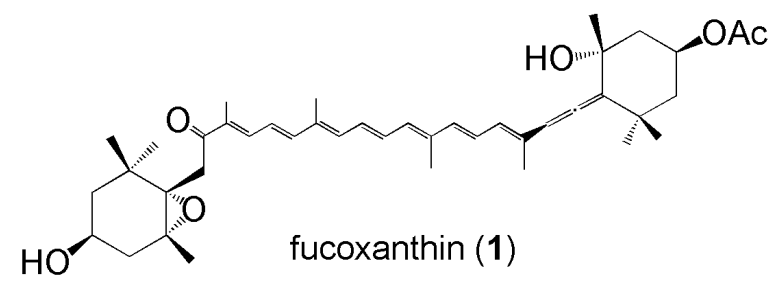

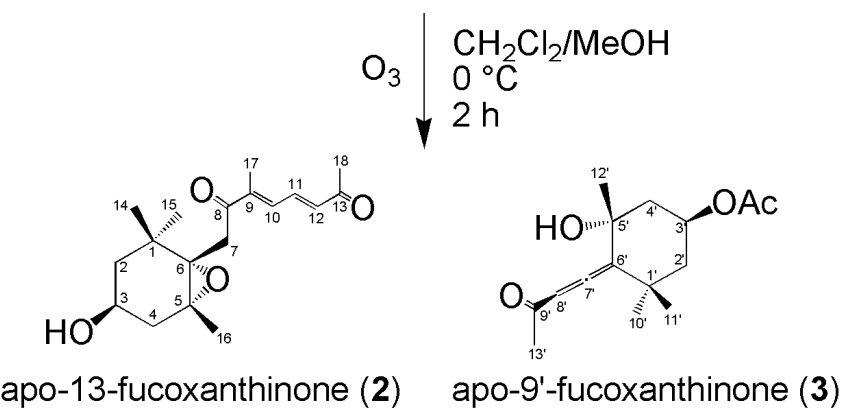

Figure 1. Synthesis of two six-membered ring derivatives (apo-13-fucoxanhinone (2) and apo-9'fucoxanthinone (3)).

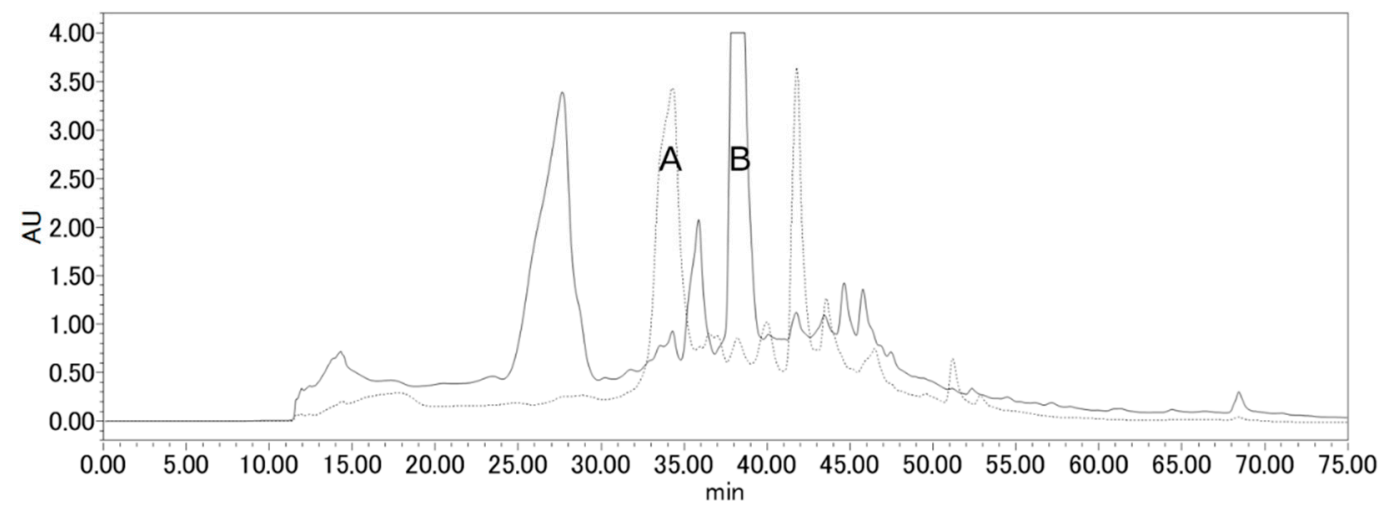

Figure 2. HPLC profile of fucoxanthin degradation compounds. Column: Mightysil RP-18 GP 250-20 column $(20 \times 250$ mm, $5 \mu \mathrm{m}$; Kanto Chemical, Tokyo, Japan); solvent A: water; solvent B: EtOH. The solvent profile was as follows (linear gradient between each step): initial conditions: $A / B=75: 25$, $1 \mathrm{~mL} / \mathrm{min} ; 1 \mathrm{~min}: \mathrm{A} / \mathrm{B}=75: 25,5 \mathrm{~mL} / \mathrm{min} ; 10 \mathrm{~min}: \mathrm{A} / \mathrm{B}=75: 25,5 \mathrm{~mL} / \mathrm{min} ; 60 \mathrm{~min}: \mathrm{A} / \mathrm{B}=0: 100$, $5 \mathrm{~mL} / \mathrm{min}$. A straight line indicates an absorbance of $215 \mathrm{~nm}$. The dashed line indicates an absorbance of $280 \mathrm{~nm}$. Peak A: apo-13-fucoxanthinone (2) (34.3 min); peak B: apo-9'-fucoxanthinone (3) (38.6 min). 
Table 1. ${ }^{1} \mathrm{H}-\mathrm{NMR}$ and ${ }^{13} \mathrm{C}-\mathrm{NMR}$ chemical shift assignments $\left(\delta=\mathrm{ppm}, \mathrm{CDCl}_{3}\right.$, reference TMS $\left.=0.00 \mathrm{ppm}\right)$ for peak A in Figure 2, apo-13-fucoxanthinone (2).

\begin{tabular}{ccc}
\hline Comp. $\mathbf{2}$ & ${ }^{\mathbf{1}_{\mathbf{H}}}$ & ${ }^{{ }^{\mathbf{3}} \mathbf{C}}$ \\
\hline $\mathrm{C}-1$ & - & 35.1 \\
$\mathrm{CH}-2$ & $1.34,1.50$ & 47.2 \\
$\mathrm{CH}-3$ & 3.81 & 64.2 \\
$\mathrm{CH}_{2}-4$ & $1.79,2.31$ & 41.6 \\
$\mathrm{C}-5$ & - & 66.1 \\
$\mathrm{C}-6$ & - & 66.7 \\
$\mathrm{CH}_{2}-7$ & $2.61,3.63$ & 41.4 \\
$\mathrm{C}-8$ & - & 198.1 \\
$\mathrm{C}-9$ & - & 143.1 \\
$\mathrm{CH}-10$ & 7.05 & 134.5 \\
$\mathrm{CH}-11$ & 7.47 & 136.7 \\
$\mathrm{CH}-12$ & 6.46 & 135.6 \\
$\mathrm{C}-13$ & - & 197.7 \\
$\mathrm{CH}_{3}-14$ & 1.03 & 24.9 \\
$\mathrm{CH}_{3}-15$ & 0.94 & 28.1 \\
$\mathrm{CH}_{3}-16$ & 1.21 & 21.0 \\
$\mathrm{CH}_{3}-17$ & 2.03 & 12.5 \\
$\mathrm{CH}_{3}-18$ & 2.35 & 28.2 \\
\hline
\end{tabular}

Table 2. ${ }^{1} \mathrm{H}-\mathrm{NMR}$ and ${ }^{13} \mathrm{C}-\mathrm{NMR}$ chemical shift assignments $\left(\delta=\mathrm{ppm}, \mathrm{CDCl}_{3}\right.$, reference TMS $\left.=0.00 \mathrm{ppm}\right)$ for peak B in Figure 2, apo-9'-fucoxanthinone (3).

\begin{tabular}{ccc}
\hline Comp. $\mathbf{3}$ & ${ }^{\mathbf{1}} \mathbf{H}$ & ${ }^{\mathbf{1 3}} \mathbf{C}$ \\
\hline $\mathrm{C}-1^{\prime}$ & - & 36.0 \\
$\mathrm{CH}_{2}-2^{\prime}$ & $1.44,2.02$ & 45.00 \\
$\mathrm{CH}-3^{\prime}$ & 5.39 & 67.4 \\
$\mathrm{CH}_{2}-4^{\prime}$ & $1.53,2.33$ & 45.04 \\
$\mathrm{C}-5^{\prime}$ & - & 72.0 \\
$\mathrm{C}-6^{\prime}$ & - & 118.5 \\
$\mathrm{C}-7^{\prime}$ & - & 209.5 \\
$\mathrm{CH}-8^{\prime}$ & 5.87 & 100.9 \\
$\mathrm{C}-9^{\prime}$ & - & 198.0 \\
$\mathrm{CH}_{3}-10^{\prime}$ & 1.16 & 31.6 \\
$\mathrm{CH}_{3}-11^{\prime}$ & 1.43 & 28.9 \\
$\mathrm{CH}_{3}-12^{\prime}$ & 1.43 & 30.8 \\
$\mathrm{CH}_{3}-13^{\prime}$ & 2.19 & 26.4 \\
$\mathrm{CH}_{3}-\mathrm{Ac}$ & 2.05 & 21.3 \\
$\mathrm{C}-\mathrm{Ac}$ & - & 170.4 \\
\hline
\end{tabular}

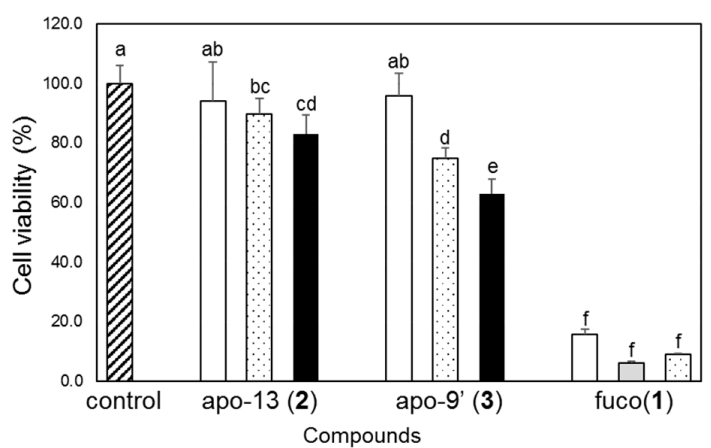

Figure 3. Concentration-dependent antiproliferative effect of apo-13-fucoxanthinone (apo-13, 2), apo-9'-fucoxanthinone (apo-9', 3), and fucoxanthin (fuco, 1) on Caco-2 cells. Caco-2 cells were cultured with apo-13 (2), apo-9' (3) and fuco (1) in supplemented medium for $72 \mathrm{~h}$. Cell viability was estimated by MTT assay and is expressed relative to the control cells treated with the vehicle alone. The pattern of each bar shows the concentration, as follows: $0 \mu \mathrm{M}$ : hatched bar, $10 \mu \mathrm{M}$ : open bar, $20 \mu \mathrm{M}$ : shaded bar, $30 \mu \mathrm{M}$ : dotted bar, $50 \mu \mathrm{M}$ : solid bar. The data represent the mean \pm standard deviation of three wells. Replicate experiments demonstrated similar trends. Values not sharing common alphabets (from a to $f$ ) were shown to be significantly different with the Tukey-Kramer test $(p<0.05)$. 


\section{Materials and Methods}

\subsection{Reagents and Conditions}

${ }^{1} \mathrm{H}$ NMR and ${ }^{13} \mathrm{C}$ NMR spectra were obtained in $\mathrm{CDCl}_{3}$ on a Bruker BioSpin spectrometer (AV 400, Bruker Corporation, Madison, MA, USA). Chemical shifts are given in ppm and referenced to $\mathrm{Me}_{4} \mathrm{Si}(\delta 0.00)$. The following abbreviations are used for the characterization of NMR signals: $\mathrm{s}=$ singlet, $\mathrm{d}=$ doublet $\mathrm{t}=$ triplet, $\mathrm{m}=$ multiplet. The ozone generator was made by combining the ozone-generating electrode ZC-60-MM (Silver Seiko Ltd., Tokyo, Japan) with a non-noise s500 air pump (approximately $1 \mathrm{~L} / \mathrm{min}$ ) (Japan Pet Design Co., Ltd., Tokyo, Japan). ESI-Orbitrap-MS spectra were recorded on a Thermo Fisher Scientific instrument (VELOS PRO, Thermo Fisher Scientific Inc., Waltham, MA, USA). The optical rotations were determined in chloroform on a Jasco instrument (P-1020-GT, JASCO Corporation, Tokyo, Japan) under ambient temperature. Reverse-phase HPLC separation of degraded fucoxanthin compounds was performed using a Waters HPLC system with

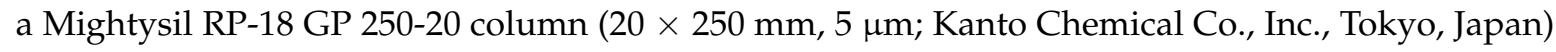
and detected at $215 \mathrm{~nm}$ and $280 \mathrm{~nm}$, simultaneously. For the HPLC conditions, solvent A was water and solvent B was ethanol. Initially, $75 \%$ of solvent $A$ at a flow rate of $1 \mathrm{~mL} / \mathrm{min}$ was used; subsequently, the flow rate was increased to $5 \mathrm{~mL} / \mathrm{min}$ for $1 \mathrm{~min}$, and this condition was maintained for $10 \mathrm{~min}$. Then, a linear gradient of $25 \%$ to $100 \%$ of solvent B was applied for $60 \mathrm{~min}$, and this condition was maintained. The HPLC analysis of compounds in medium for the antiproliferation assay was performed as follows: fucoxanthin (1), apo-13-fucoxanthinone (2), and apo-9'-fucoxanthinone (3) were analyzed by HPLC (using an LC-20AT pump, an SPD-M10A photodiode array detector, and a CTO-10AS column oven at a constant temperature of $25^{\circ} \mathrm{C}$; Shimadzu Corporation, Kyoto, Japan) on an ODS-80Ts column $(2.0 \times 150 \mathrm{~mm})$ with an ODS-S1 precolumn $(2.0 \times 10 \mathrm{~mm}$; Tosoh Corporation, Tokyo, Japan). An isocratic analysis was performed at a flow rate of $0.2 \mathrm{~mL} / \mathrm{min}$ with acetonitrile/methanol/water $(75: 15: 10, v / v / v)$ containing $0.1 \%$ ammonium acetate for fucoxanthin (1) or acetonitrile/methanol/water (45:9:46, $v / v / v)$ containing 0.1\% ammonium acetate for apo-13-fucoxanthinone (2) and apo-9'-fucoxanthinone (3), respectively. These compounds were quantified from the peak area at $450 \mathrm{~nm}$ for fucoxanthin (1), $288 \mathrm{~nm}$ for apo-13-fucoxanthinone (2), and $232 \mathrm{~nm}$ for apo-9'-fucoxanthinone (3), respectively, using an authentic standard calibration curve. Dry wakame from China was purchased from a local market in Tsukuba, Japan. Human colorectal carcinoma Caco-2 cells were obtained from the American Type Culture Collection (Rockville, MD, USA). Dulbecco's modified Eagle's medium (DMEM) was purchased from Nissui Pharmaceutical Co., Ltd. (Tokyo, Japan). The DMEM used a low glucose-type (1.0 g/L glucose), so we increased the glucose concentration to $4.5 \mathrm{~g} / \mathrm{L}$. Tetrahydrofuran (THF) was purchased from Nacalai Tesque, Inc. (Kyoto, Japan). THF was purified in a neutral alumina column just before use. All reagents and solvents used were reagent grade.

\subsection{Synthesis of Two Six-Membered Ring Derivatives \{apo-13-Fucoxanthinone (2) and apo-9'-Fucoxanthinone (3)\}}

Fucoxanthin was purified from wakame (Undaria pinnatifida). The extraction solvents and purification method have been referenced in previous experiments [30]. A mixed solvent (chloroform/methanol/water 5:4:1) was used for the extraction and subsequent purification of the residue on the silica gel (ethyl acetate/toluene 1:5) through chromatography, resulting in pure fucoxanthin $(1.09 \mathrm{mg} / \mathrm{g}$ dry wakame). The ${ }^{1} \mathrm{H}-\mathrm{NMR}$ and ${ }^{13} \mathrm{C}-\mathrm{NMR}$ spectra were identical to those previously reported. The purified fucoxanthin $(58 \mathrm{mg}, 88 \mu \mathrm{mol})$ was dissolved in dichloromethane/methanol $(39 \mathrm{~mL} / 66 \mathrm{~mL})$ and cooled to $0{ }^{\circ} \mathrm{C}$. Ozone gas from a homemade ozone generator was bubbled though the cooled and stirred mixture for $2 \mathrm{~h}$. Afterwards, the ozone gas was replaced with nitrogen gas, dimethyl sulfide $(130 \mu \mathrm{L}$, $1.77 \mathrm{mmol}$ ) was added to the mixture, and the mixture was stirred from $0{ }^{\circ} \mathrm{C}$ to room temperature for a further $2 \mathrm{~h}$. Then, silica gel (35 g) was added to the mixture, and the solvent was removed under reduced pressure to absorb the reaction product into the silica gel. Thereafter, the polar substances were removed by silica gel column chromatography (ethyl acetate/ $n$-hexane 2:1). The obtained syrup 
was purified by reverse phase HPLC to obtain compound 2 (apo-13-fucoxanthinone, $1.87 \mathrm{mg}$, 6.9\%) and compound 3 (apo-9'-fucoxanthinone, $7.85 \mathrm{mg}$, 33\%). All experiments were done under dim light in order to minimize the isomerization and degradation of fucoxanthin derivatives due to light irradiation. Compound 2 (apo-13-fucoxanthinone): $[\alpha]_{\mathrm{D}}^{25}=-13\left(c=0.06\right.$, chloroform); ${ }^{1} \mathrm{H}-\mathrm{NMR}$ $\left(400 \mathrm{MHz}, \mathrm{CDCl}_{3}\right), \delta=0.94$ (s, 3H, Me-15), 1.03 (s, 3H, Me-14), 1.21 (s, 3H, Me-16), 1.34 and 1.50 (each $\mathrm{m}, 2 \mathrm{H}, \mathrm{H}-2 \mathrm{a}$ and $\mathrm{H}-2 \mathrm{~b}$ ), 1.79 and 2.31 (each $\mathrm{m}, 2 \mathrm{H}, \mathrm{H}-4 \mathrm{a}$ and $\mathrm{H}-4 \mathrm{~b}), 2.03$ (s, 3H, Me-17), 2.35 (s, 3H, Me-18), 2.61 (d, 1H, Jgem 18.6 Hz, H-7a), 3.63 (d, 1H, Jgem 19.0 Hz, H-7b), 3.81 (m, 1H, H-3), 6.46 (d, 1H, $\left.J_{11,12} 15.4 \mathrm{~Hz}, \mathrm{H}-12\right), 7.05$ (d, 1H, J10,11 $\left.11.2 \mathrm{~Hz}, \mathrm{H}-10\right), 7.47$ (dd, 1H, J10,11 $11.3 \mathrm{~Hz}, J_{11,12} 15.4 \mathrm{~Hz}, \mathrm{H}-11$ ); ${ }^{13} \mathrm{C}-\mathrm{NMR}\left(100 \mathrm{MHz}, \mathrm{CDCl}_{3}\right), \delta=12.5$ (C-17), 21.0 (C-16), 24.9 (C-14), 28.1 (C-15), 28.2 (C-18), 35.1 (C-1), 41.4 (C-7), 41.6 (C-4), 47.2 (C-2), 64.2 (C-3), 66.1 (C-5), 66.7 (C-6), 134.5 (C-10), 135.6 (C-12), 136.7 (C-11), 143.1 (C-9), 197.7 (C-13), 198.1 (C-8); ESI-Orbitrap-MS, calcd. for $\mathrm{C}_{18} \mathrm{H}_{27} \mathrm{O}_{4}{ }^{+}[\mathrm{M}+\mathrm{H}]^{+}$: 307.1904, found $m / z$ : 307.1905. Compound 3 (apo-9'-fucoxanthinone): $[\alpha]_{\mathrm{D}}^{25}=-19\left(c=0.08\right.$, chloroform); ${ }^{1} \mathrm{H}-\mathrm{NMR}$ $\left(400 \mathrm{MHz}, \mathrm{CDCl}_{3}\right), \delta=1.16\left(\mathrm{~s}, 3 \mathrm{H}, \mathrm{Me}-10^{\prime}\right), 1.43\left(\mathrm{~s}, 6 \mathrm{H}, \mathrm{Me}-11^{\prime}\right.$ and $\left.\mathrm{Me}-12^{\prime}\right), 1.44\left(1 \mathrm{H}, \mathrm{H}-2^{\prime} \mathrm{a}\right), 1.53(\mathrm{dd}$, 1H, J 11.4 Hz, J 12.9 Hz, H-4'a), 2.02 (dd, 1H, J 2.2 Hz, J 4.3 Hz, H-2'b), 2.05 (s, 3H, Ac), 2.19 (s, 3H, Me-13'), 2.33 (ddd, 1H, J $2.2 \mathrm{~Hz}, J 4.3 \mathrm{~Hz}, J 12.9 \mathrm{~Hz}, \mathrm{H}-4^{\prime}$ b), 5.39 (tt, 1H, J $4.2 \mathrm{~Hz}, J 11.5 \mathrm{~Hz}, \mathrm{H}-3^{\prime}$ ), $5.87(\mathrm{~s}, 1 \mathrm{H}, \mathrm{H}-8) ;{ }^{13} \mathrm{C}-\mathrm{NMR}(100 \mathrm{MHz}), \delta=21.3\left(\mathrm{OCOCH}_{3}\right), 26.4\left(\mathrm{C}-13^{\prime}\right), 28.9\left(\mathrm{C}-11^{\prime}\right), 30.8\left(\mathrm{C}-12^{\prime}\right)$, $31.6\left(\mathrm{C}-10^{\prime}\right), 36.0\left(\mathrm{C}-1^{\prime}\right), 45.00\left(\mathrm{C}-2^{\prime}\right), 45.04\left(\mathrm{C}-4^{\prime}\right), 67.4\left(\mathrm{C}-3^{\prime}\right), 72.0\left(\mathrm{C}-5^{\prime}\right), 100.9\left(\mathrm{C}-8^{\prime}\right), 118.5\left(\mathrm{C}-6^{\prime}\right)$, $170.4\left(\mathrm{OCOCH}_{3}\right), 198.0\left(\mathrm{C}-9^{\prime}\right), 209.5\left(\mathrm{C}-7^{\prime}\right)$; ESI-Orbitrap-MS, calcd. for $\mathrm{C}_{15} \mathrm{H}_{23} \mathrm{O}_{4}{ }^{+}[\mathrm{M}+\mathrm{H}]^{+}: 267.1591$, found $m / z: 267.1595$.

\subsection{Antiproliferation Activity of Caco-2 Cells by apo-13-Fucoxanthinone (2) and apo-9'-Fucoxanthinone (3)}

Caco-2 cells were cultured in DMEM supplemented with $0.1 \mathrm{mM}$ nonessential amino acids, $10 \%$ heat-inactivated fetal bovine serum, $4 \mathrm{mM}$ L-glutamine, and antibiotics ( 40 units $/ \mathrm{mL}$ penicillin and $40 \mathrm{mg} / \mathrm{mL}$ streptomycin) [36]. The culture was carried out at $37^{\circ} \mathrm{C}$ in a humidified atmosphere with $5 \% \mathrm{CO}_{2}$ in air. In order to evaluate the effects of these compounds on the viability of the cells, the cells were seeded at a density of $5 \times 10^{3}$ cells per well containing $100 \mu \mathrm{L}$ of culture medium in 96-well plates for $24 \mathrm{~h}$, and fresh medium was used for the treatment with the compounds described below. Media containing the compounds were prepared using a liquid-drying method, as in our previous study [37]. In brief, fucoxanthin and the degraded compounds dissolved in the purified tetrahydrofuran (THF) and were added to the culture medium. The control culture received only THF in the medium (vehicle alone). The THF in the medium was dried in a centrifugal evaporator. The medium was passed through a $0.2-\mu \mathrm{m}$ filter to be sterilized, and was then used as fresh medium supplemented with the compounds. To determine the concentration of the compounds, one part of the fresh medium was diluted 41-fold with ethanol for apo-13-fucoxanthinone (2) and apo-9'-fucoxanthinone (3), or with dimethyl sulfoxide/methanol $(2: 7, v / v)$ for fucoxanthin (1), respectively, and subjected to HPLC analysis. After $72 \mathrm{~h}$ of cultivation, cell viability was evaluated by 3-(4,5-dimethylthiazol-2-yl)-2,5-diphenyl tetrazolium bromide (MTT) assay [31]. Data represent means \pm standard deviations. The antiproliferation experiments were done under dim yellow light in order to minimize the isomerization and degradation of xanthophylls due to light irradiation. The results were analyzed by one-way ANOVA and the Tukey-Kramer test in order to identify significant differences between treatments, with $p$-values $<0.05$ considered significant.

\section{Conclusions}

We succeeded in decomposing fucoxanthin under very mild and neutral conditions. The decomposition obtained here had the same structure as degraded fucoxanthin found in nature. By refining HPLC more precisely, there is a good possibility of obtaining a new degradation product. Currently, more detailed isolation and purification processes are being conducted. In addition, it was found that the two types of degradation product obtained here cause growth suppression in Caco- 2 cells. In particular, the compound with an allene structure preferentially inhibited proliferation 
compared to that without an allene structure. From this result, we predict that an allene structure is important to inhibit the proliferation of Caco-2 cells.

Supplementary Materials: The following are available online at http:/ /www.mdpi.com/1660-3397/16/8/275/s1, Figure S1: HSQC-NMR chart of apo-13-fucoxanthinone (2), Figure S2: HSQC-NMR chart of apo-9'-fucoxanthinone (3).

Author Contributions: S.K. and W.T. conceived and designed the experiments; S.K. and E.K.-N. performed the experiments; S.K. and E.K.-N. analyzed the data; W.T. contributed reagents/materials/analysis tools; S.K. wrote the paper.

Funding: This research received no external funding.

Acknowledgments: This research was conducted using NMR and MS equipment owned by the Advanced Analysis Center, NARO. We thank H. Ono (Advanced Analysis Center, NARO, JP) and his staff for the NMR, ESI-Orbitrap-MS measurements.

Conflicts of Interest: The authors declare no conflict of interest. The founding sponsors had no role in the design of the study; in the collection, analyses, or interpretation of data; in the writing of the manuscript, or in the decision to publish the results.

\section{References}

1. Kim, S.M.; Jung, Y.J.; Kwon, O.N.; Cha, K.H.; Um, B.H.; Chung, D.; Pan, C.H. A potential commercial source of fucoxanthin extracted from the microalga Phaeodactylum tricornutum. Appl. Biochem. Biotechnol. 2012, 166, 1843-1855. [CrossRef] [PubMed]

2. Kanazawa, K.; Ozaki, Y.; Hashimoto, T.; Das, S.K.; Matsushita, S.; Hirano, M.; Okada, T.; Komoto, A.; Mori, N.; Nakatsuka, M. Commercial-scale preparation of biofunctional fucoxanthin from waste parts of brown sea algae Laminalia japonica. Food Sci. Technol. Res. 2008, 14, 573-582. [CrossRef]

3. Xiao, X.H.; Si, X.X.; Yuan, Z.Q.; Xu, X.F.; Li, G.K. Isolation of fucoxanthin from edible brown algae by microwave-assisted extraction coupled with high-speed countercurrent chromatography. J. Sep. Sci. 2012, 35, 2313-2317. [CrossRef] [PubMed]

4. Mori, K.; Ooi, T.; Hiraoka, M.; Oka, N.; Hamada, H.; Tamura, M.; Kusumi, T. Fucoxanthin and its metabolites in edible brown algae cultivated in deep seawater. Mar. Drugs 2004, 2, 63-72. [CrossRef]

5. Jaswir, I.; Noviendri, D.; Salleh, H.M.; Miyashita, K. Fucoxanthin extractions of brown seaweeds and analysis of their lipid fraction in methanol. Food Sci. Technol. Res. 2012, 18, 251-257. [CrossRef]

6. Jaswir, I.; Noviendri, D.; Salleh, H.M.; Taher, M.; Miyashita, K.; Ramli, N. Analysis of fucoxanthin content and purification of all-trans-fucoxanthin from Turbinaria turbinata and Sargassum plagyophyllum by $\mathrm{SiO}_{2}$ open column chromatography and reversed phase-HPLC. J. Liq. Chromatogr. Relat. Technol. 2013, 36, 1340-1354.

7. Kim, S.M.; Kang, S.W.; Kwon, O.N.; Chung, D.; Pan, C.H. Fucoxanthin as a major carotenoid in isochrysis aff. galbana: Characterization of extraction for commercial application. J. Korean Soc. Appl. Biol. Chem. 2012, 55, 477-483. [CrossRef]

8. Pasquet, V.; Cherouvrier, J.R.; Farhat, F.; Thiery, V.; Piot, J.M.; Berard, J.B.; Kaas, R.; Serive, B.; Patrice, T.; Cadoret, J.P.; et al. Study on the microalgal pigments extraction process: Performance of microwave assisted extraction. Process Biochem. 2011, 46, 59-67. [CrossRef]

9. Xia, S.; Wang, K.; Wan, L.L.; Li, A.F.; Hu, Q.; Zhang, C.W. Production, characterization, and antioxidant activity of fucoxanthin from the marine diatom Odontella aurita. Mar. Drugs 2013, 11, 2667-2681. [CrossRef] [PubMed]

10. Peng, J.; Yuan, J.P.; Wu, C.F.; Wang, J.H. Fucoxanthin, a marine carotenoid present in brown seaweeds and diatoms: Metabolism and bioactivities relevant to human health. Mar. Drugs 2011, 9, 1806-1828. [CrossRef] [PubMed]

11. Okuzumi, J.; Takahashi, T.; Yamane, T.; Kitao, Y.; Inagake, M.; Ohya, K.; Nishino, H.; Tanaka, Y. Inhibitory effects of fucoxanthin, a natural carotenoid, on $N$-ethyl- $N^{\prime}$-nitro- $N$-nitrosoguanidine-induced mouse duodenal carcinogenesis. Cancer Lett. 1993, 68, 159-168. [CrossRef]

12. Das, S.K.; Hashimoto, T.; Baba, M.; Nishino, H.; Komoto, A.; Kanazawa, K. Japanese kelp (kombu) extract suppressed the formation of aberrant crypt foci in azoxymethane challenged mouse colon. J. Clin. Biochem. Nutr. 2006, 38, 119-125. [CrossRef]

13. Kotake-Nara, E.; Kushiro, M.; Zhang, H.; Sugawara, T.; Miyashita, K.; Nagao, A. Carotenoids affect proliferation of human prostate cancer cells. J. Nutr. 2001, 131, 3303-3306. [CrossRef] [PubMed] 
14. Hosokawa, M.; Kudo, M.; Maeda, H.; Kohno, H.; Tanaka, T.; Miyashita, K. Fucoxanthin induces apoptosis and enhances the antiproliferative effect of the PPAR $\gamma$ ligand, troglitazone, on colon cancer cells. Biochim. Biophys. Acta 2004, 1675, 113-119. [CrossRef] [PubMed]

15. Das, S.K.; Hashimoto, T.; Shimizu, K.; Yoshida, T.; Sakai, T.; Sowa, Y.; Komoto, A.; Kanazawa, K. Fucoxanthin induces cell cycle arrest at $\mathrm{G}_{0} / \mathrm{G}_{1}$ phase in human colon carcinoma cells through up-regulation of p21WAF1/Cip1. Biochim. Biophys. Acta 2005, 1726, 328-335. [CrossRef] [PubMed]

16. Funahashi, H.; Imai, T.; Mase, T.; Sekiya, M.; Yokoi, K.; Hayashi, H.; Shibata, A.; Hayashi, T.; Nishikawa, M.; Suda, N.; et al. Seaweed prevents breast cancer? Jpn. J. Cancer Res. 2001, 92, 483-487. [CrossRef] [PubMed]

17. Funahashi, H.; Imai, T.; Tanaka, Y.; Tsukamura, K.; Hayakawa, Y.; Kikumori, T.; Mase, T.; Itoh, T.; Nishikawa, M.; Hayashi, H.; et al. Wakame seaweed suppresses the proliferation of 7,12-dimethylbenz(a)anthracene-induced mammary tumors in rats. Jpn. J. Cancer Res. 1999, 90, 922-927. [CrossRef] [PubMed]

18. Okai, Y.; Higashiokai, K.; Nakamura, S. Identification of heterogenous antimutagenic activities in the extract of edible brown seaweeds, Laminaria-japonica (Makonbu) and Undaria-pinnatifida (Wakame) by the umu gene expression system in Salmonella typhimurium (TA1535/pSK1002). Mutat. Res. 1993, 303, 63-70. [CrossRef]

19. Teas, J.; Vena, S.; Cone, D.L.; Irhimeh, M. The consumption of seaweed as a protective factor in the etiology of breast cancer: Proof of principle. J. Appl. Phycol. 2013, 25, 771-779. [CrossRef] [PubMed]

20. Moghadamtousi, S.Z.; Karimian, H.; Khanabdali, R.; Razavi, M.; Firoozinia, M.; Zandi, K.; Kadir, H.A. Anticancer and antitumor potential of fucoidan and fucoxanthin, two main metabolites isolated from brown algae. Sci. World J. 2014, 2014, 768323. [CrossRef]

21. Kumar, S.R.; Hosokawa, M.; Miyashita, K. Fucoxanthin: A marine carotenoid exerting anti-cancer effects by affecting multiple mechanisms. Mar. Drugs 2013, 11, 5130-5147. [CrossRef] [PubMed]

22. Satomi, Y. Antitumor and cancer-preventative function of fucoxanthin: A marine carotenoid. Anticancer Res. 2017, 37, 1557-1562. [CrossRef] [PubMed]

23. Maeda, H.; Hosokawa, M.; Sashima, T.; Takahashi, N.; Kawada, T.; Miyashita, K. Fucoxanthin and its metabolite, fucoxanthinol, suppress adipocyte differentiation in 3T3-L1 cells. Int. J. Mol. Med. 2006, 18, 147-152. [CrossRef] [PubMed]

24. Maeda, H.; Hosokawa, M.; Sashima, T.; Funayama, K.; Miyashita, K. Fucoxanthin from edible seaweed, Undaria pinnatifida, shows antiobesity effect through UCP1 expression in white adipose tissues. Biochem. Biophys. Res. Commun. 2005, 332, 392-397. [CrossRef] [PubMed]

25. Miyashita, K.; Nishikawa, S.; Beppu, F.; Tsukui, T.; Abe, M.; Hosokawa, A. The allenic carotenoid fucoxanthin, a novel marine nutraceutical from brown seaweeds. J. Sci. Food Agric. 2011, 91, 1166-1174. [CrossRef] [PubMed]

26. Heo, S.J.; Yoon, W.J.; Kim, K.N.; Oh, C.; Choi, Y.U.; Yoon, K.T.; Kang, D.H.; Qian, Z.J.; Choi, I.W.; Jung, W.K. Anti-inflammatory effect of fucoxanthin derivatives isolated from Sargassum siliquastrum in lipopolysaccharide-stimulated RAW 264.7 macrophage. Food Chem. Toxicol. 2012, 50, 3336-3342. [CrossRef] [PubMed]

27. Sugawara, T.; Matsubara, K.; Akagi, R.; Mori, M.; Hirata, T. Antiangiogenic activity of brown algae fucoxanthin and its deacetylated product, fucoxanthinol. J. Agric. Food. Chem. 2006, 54, 9805-9810. [CrossRef] [PubMed]

28. Fung, A.; Hamid, N.; Lu, J. Fucoxanthin content and antioxidant properties of Undaria pinnatifida. Food Chem. 2013, 136, 1055-1062. [CrossRef] [PubMed]

29. Kotake-Nara, E.; Sugawara, T.; Nagao, A. Antiproliferative effect of neoxanthin and fucoxanthin on cultured cells. Fish. Sci. 2005, 71, 459-461. [CrossRef]

30. Komba, S.; Kotake-Nara, E.; Machida, S. Fucoxanthin derivatives: Synthesis and their chemical properties. J. Oleo Sci. 2015, 64, 1009-1018. [CrossRef] [PubMed]

31. Mosmann, T. Rapid colorimetric assay for cellular growth and survival: Application to proliferation and cytotoxicity assays. J. Immunol. Methods 1983, 65, 55-63. [CrossRef]

32. Kim, E.A.; Kim, S.Y.; Ye, B.R.; Kim, J.; Ko, S.C.; Lee, W.W.; Kim, K.N.; Choi, I.W.; Jung, W.K.; Heo, S.J. Anti-inflammatory effect of Apo-9'-fucoxanthinone via inhibition of MAPKs and NF- $\mathrm{kB}$ signaling pathway in LPS-stimulated RAW 264.7 macrophages and zebrafish model. Int. Immunopharmacol. 2018, 59, 339-346. [CrossRef] [PubMed]

33. Chae, D.; Manzoor, Z.; Kim, S.C.; Kim, S.; Oh, T.H.; Yoo, E.S.; Kang, H.K.; Hyun, J.W.; Lee, N.H.; Ko, M.H.; et al. Apo-9'-fucoxanthinone, isolated from Sargassum muticum, inhibits CpG-induced inflammatory response by attenuating the mitogen-activated protein kinase pathway. Mar. Drugs 2013, 11, 3272-3287. [CrossRef] [PubMed] 
34. Yang, E.J.; Ham, Y.M.; Lee, W.J.; Lee, N.H.; Hyun, C.G. Anti-inflammatory effects of apo-9'-fucoxanthinone from the brown alga, Sargassum muticum. DARU J. Pharm. Sci. 2013, 21, 62. [CrossRef] [PubMed]

35. Kang, J.I.; Yoo, E.S.; Hyun, J.W.; Koh, Y.S.; Lee, N.H.; Ko, M.H.; Ko, C.S.; Kang, H.K. Promotion effect of apo-9'-fucoxanthinone from Sargassum muticum on hair growth via the activation of Wnt/ $\beta$-catenin and VEGF-R2. Biol. Pharm. Bull. 2016, 39, 1273-1283. [CrossRef] [PubMed]

36. Sugawara, T.; Kushiro, M.; Zhang, H.; Nara, E.; Ono, H.; Nagao, A. Lysophosphatidylcholine enhances carotenoid uptake from mixed micelles by Caco-2 human intestinal cells. J. Nutr. 2001, 131, 2921-2927. [CrossRef] [PubMed]

37. Kotake-Nara, E.; Hase, M.; Kobayashi, M.; Nagao, A. 3'-Hydroxy- $\varepsilon$, $\varepsilon$-caroten-3-one inhibits the differentiation of 3T3-L1 cells to adipocytes. Biosci. Biotechnol. Biochem. 2016, 80, 518-523. [CrossRef] [PubMed]

2018 by the authors. Licensee MDPI, Basel, Switzerland. This article is an open access article distributed under the terms and conditions of the Creative Commons Attribution (CC BY) license (http:// creativecommons.org/licenses/by/4.0/). 